\title{
CENTRIFUGE MODELING OF LARGE DIAMETER UNDERGROUND PIPES SUBJECTED TO HEAVY TRAFFIC LOADS
}

\author{
Boris Rakitin, boris.rakitin@gmail.com \\ Ming Xu \\ Tsinghua University, Beijing 100084, China
}

\begin{abstract}
Large diameter pipes, as well as heavy vehicles, have been becoming increasingly prevalent, which impose uncertainties on pipe design. This paper describes the procedure and results of a series of geotechnical centrifuge tests performed on a large $1400 \mathrm{~mm}$-diameter reinforced concrete pipe with a footing subjected to heavy traffic loading. The influence of soil cover depth, as well as the positions and magnitude of traffic loads, on the bending moments of the pipe were investigated. A heavy truck with a maximum load of $850 \mathrm{kN}$ was simulated in the majority of the tests, and a medium truck of $252 \mathrm{kN}$ was also simulated. The centrifuge test results were found to be in reasonable agreement with those from full-scale tests. The pipe would experience the most unfavorable conditions when the heaviest axis of the traffic vehicle was located directly above the pipe crown. A deeper soil cover would lead to higher initial stresses in the pipe, as well as reduced influence of traffic load. However, even for a soil cover depth of $4 \mathrm{~m}$, there is significant bending moment induced by the heavy truck loading, which could not be ignored during the pipeline design. Comparison was made between the centrifuge test results and several widely adopted design methods, and unconservative calculation results were noticed for large diameter rigid pipes lying at a shallow soil cover depth subjected to heavy traffic loading.

Keywords: soil-structure interaction, reinforced concrete pipe, heavy traffic loads, geotechnical centrifuge testing, full-scale testing.
\end{abstract}

\section{Introduction}

In civil and road construction, underground pipelines are widely used for different purposes, such as transporting water, chemicals and gases. Municipal water distribution and wastewater infrastructure systems are of national importance for any country. However, water leakage becomes a serious problem in many countries. For example, in the United States of America, it is estimated that 9.8 trillion liters of treated drinking water (or $17 \%$ of all pumped water) are lost annually through leaking pipes, resulting in a cost of $\$ 4.1$ billion in wasted electricity every year [1]. In China, 6 trillion liters of treated drinking water are leaked every year, while the leakage rate is found to be as high as $23 \%$ in some cities [2]. Thus, poor performance of pipelines leads to significant economic and water recourse losses, which become more and more unsustainable and severe in many countries, particularly considering population growth as well as water resource shortages in many areas around the world. Furthermore, bacteria would enter pipes though leakage, which impose threats to public health [3].

There are many factors influencing the performance of underground rigid pipes [4]. Davies [5] investigated factors influencing the deterioration of pipes, highlighting the impact of heavy surface traffic loading moving around construction sites. After examination of underground pipeline defects, Lester and Farrar [6] found that the number of cracked and fractured pipes underneath main roads with heavy vehicle loading is much higher in comparison with that below minor roads. Trott and Gaunt [7] noticed that the most severe loading conditions occurred due to heavy construction traffic traversing pipes during the construction process before rigid pavement was completed.

With the development of the automotive industry, new kinds of heavy vehicles appear, leading to much higher traffic loads on transport infrastructure. In some cases the increase in traffic loads leads to transport infrastructure failure. Because of the high importance of this problem, U.S. Federal Highway Administration is studying the possibility for increasing truck weight limits from the current 36 tones to 44 tones and even as high as 67 tones [8].

Boussinesq [9] developed a solution for the stress at any point in a homogeneous, elastic and isotropic medium, caused by a point load applied on the surface of an infinitely large half space. Based on Boussinesq equations Young and O'Reilly [10] developed method for estimating the vertical stress on underground pipe caused by the traffic wheel load. Various of charts based on Boussinesq method were developed, which are still in use in BS EN 1295-1 [11]. Other researchers, like Marston and Anderson [12], Spangler [13] and Burns and Richard [14], introduced their theories about influence of loads on underground pipelines.

With the advancement of manufacturing and installation technologies, underground pipelines with an inner diameter more than $900 \mathrm{~mm}$ are getting increasingly popular for infrastructure construction. For example, the demand for large diameter pipes for water and wastewater will rise 6.2 percent annually for the next four years up to $60046 \mathrm{~km}$ (197 million feet) in the United States [15]. During the construction and service period, the pipes must support pressures from soil and vehicle loads applied at the soil surface. 


\section{Теория расчета строительных конструкций}

A number of studies have been carried out to analyze the behavior of underground pipelines subjected to different kinds of vehicle loading. Pocock [16] measured the bending strain developed in a shallow buried pipeline due to traffic loads. The measured bending strains were found to increase linearly with applied load, and for any given load, strains tended to decrease with increasing vehicle speed. Taylor and Lawrence [17] noticed that the response of cast iron pipeline to heavy vehicles depended on structure of the pavement, the depth of the cover and pipe bedding. Arockiasamy [18] conducted full-scale tests on large diameter plastic and metal pipes subjected to truck loading. Moore [19] conducted indoor full-scale tests to study the joint behavior of $0.6 \mathrm{~m}$ and $1.2 \mathrm{~m}$ diameter reinforced concrete pipes buried at shallow depths when the vehicle wheel is located directly above the joint or within a close distance to the joint.

Despite the limited studies on large diameter pipes, the majority of previous studies were carried out on small diameter pipes (inner diameter less than $900 \mathrm{~mm}$ ) at shallow depths. In many cases, a maximum vehicle weight up to $300 \mathrm{kN}$ was studied, which corresponds to a medium commercial truck. Uncertainties exist about reinforced concrete pipes with an inner diameter greater than $1000 \mathrm{~mm}$ under much heavier traffic loading, while such a situation is becoming increasingly common in recent years. Furthermore, in previous studies, the soil cover is usually of a shallow depth; usually less than $2 \mathrm{~m}$. However, in many situations the pipes have to be buried at much deeper locations due to design specifications such as the minimum requirement of soil cover depth in seasonally frozen ground.

The aim of this paper is to present the findings from a series of geotechnical centrifuge tests, which were carried out to investigate the behavior of a $1400 \mathrm{~mm}$-diameter reinforced concrete pipe under different vehicle loading, including those from a heavy truck with a maximum load of $850 \mathrm{kN}$. The effect of soil cover depth varying from $1 \mathrm{~m}$ to $4 \mathrm{~m}$ was also studied. No rigid pavement structure was simulated in the tests, which was considered to be a more unfavorable situation for the pipe [20].

\section{Geotechnical centrifuge testing}

\subsection{Test facility}

Geotechnical centrifuge testing has been successfully carried out in investigating a wide range of soil-pipeline interaction problems, including the deformation of pipelines subject to vertical faulting [21], upheaval buckling [22], [23], surface loading [24], and the effect of tunneling on adjacent pipelines [25]. The principles and scaling laws for geotechnical centrifuge testing were discussed in detail by Schofield [26]. In comparison with full-scale field testing, centrifuge modeling has the advantage that parametric studies could be performed with relative ease, and soil properties with greater homogeneity could be achieved in well controlled laboratory conditions.

All centrifuge tests presented in this paper were conducted using the 50 g-ton geotechnical beam centrifuge at Tsinghua University in Beijing with a nominal radius of $2.0 \mathrm{~m} \mathrm{[27]}$, as shown in Fig. 1. The centrifuge is equipped with an on-arm data acquisition system which can be controlled remotely. A modified aluminum alloy strongbox was used for all centrifuge tests, which provides an inner space of $600 \mathrm{~mm}$ in length, $130 \mathrm{~mm}$ in width, and $535 \mathrm{~mm}$ in height. To permit observation of soil deformations during flight, this strongbox was equipped with a $50 \mathrm{~mm}$-thick transparent Plexiglas window on the front wall.

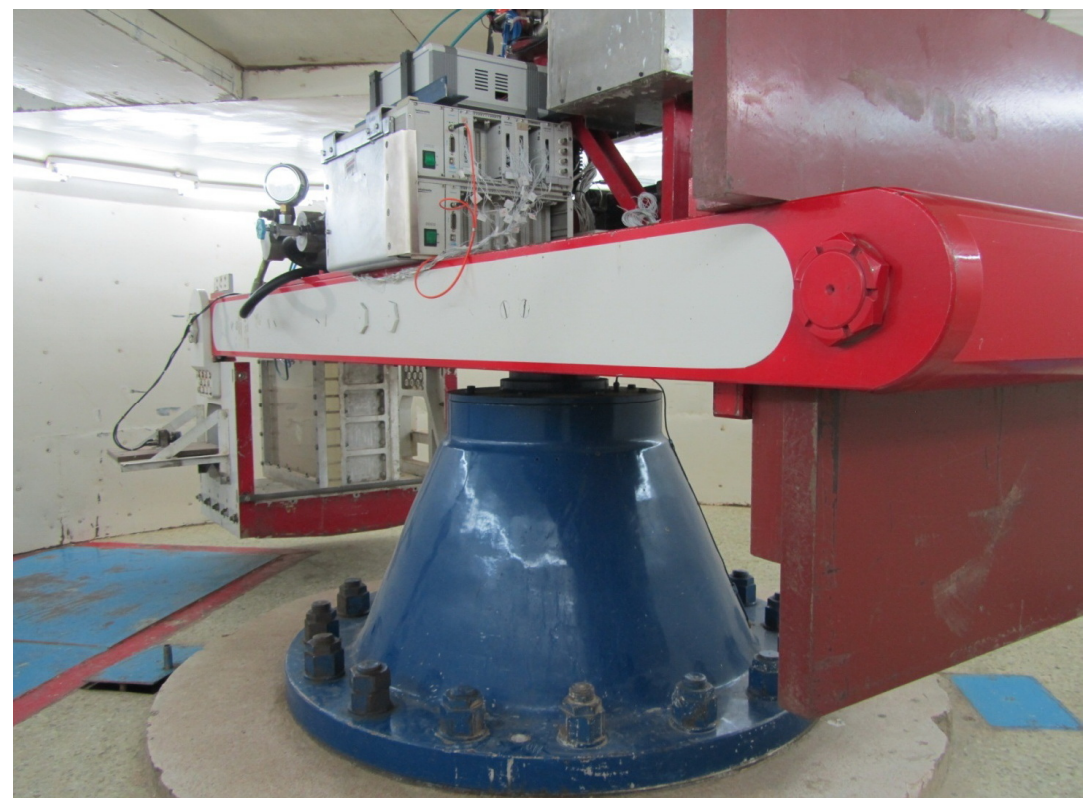

Fig. 1. The 50 g-ton geotechnical beam centrifuge at Tsinghua University 


\subsection{The pipe model and loading system}

A hollow aluminum cylinder was used to simulate a typical reinforced concrete pipe Sb-Gm $1400 \times 2,500$-Type 1-DNA EN 1916, according to BS EN 1916 [28], with an inner diameter of $1400 \mathrm{~mm}$ and a wall thickness of $165 \mathrm{~mm}$ (Fig. 2). The pipes had a $750 \mathrm{~mm}$ wide footing (see Fig. 2a), in contrast to smaller pipes without footing which had been studied previously. This footing has the benefit of easier pipe installation and better stress distribution in the pipe cross section, because of the surface-to-surface contact of the pipe footing with the soil bedding.

The prototype pipe has a bell-and-spigot joint, as demonstrated in Fig. 2c. The joint is sealed with a compressible rubber gasket, the thickness of which is $24 \mathrm{~mm}$. This kind of joint allows a restricted pipe rotation of $0^{\circ}-5^{\circ}$ [29], as well as limited vertical and horizontal relative displacements of two adjacent pipes. Due to the flexible joint, a pipe is not expected to be significantly influenced by the deformation of an adjacent pipe. The pipe has a working length of $2500 \mathrm{~mm}$, while the distance between the two rear wheels is $2830 \mathrm{~mm}$ for the heavy truck and $2043 \mathrm{~mm}$ for the medium truck used in this study. Thus when a truck is traversing the pipeline with one rear wheel exactly above the middle of a pipe, the position of another rear wheel is also approximately above the middle of the adjacent pipe (also see Fig. 8b). Therefore, one pipe bearing half truck (e.g. one front wheel and one rear wheel for the heavy truck) at the central cross section of the pipe is simulated in the centrifuge testing.

All tests were performed at an acceleration level, $\mathrm{N}$, of 20 times normal gravity (i.e., $20 \mathrm{~g}$ ). Hence all length dimensions were scaled down by a factor of 20 . To maintain the similarity of the bending moment between the model and the prototype, the bending stiffness EI should be scaled as:

$$
\frac{E_{p} I_{p}}{E_{m} I_{m}}=N^{4}
$$

where $E_{p}$ and $E_{m}$ are the elastic modulus for the prototype and model materials, which is $30 \mathrm{GPa}$ for concrete and $70 \mathrm{GPa}$ for aluminum respectively. $I_{p}$ and $I_{m}$ are the moments of inertia for the prototype and model pipes, respectively. The aluminum model pipe was therefore designed with an inner diameter $70 \mathrm{~mm}$ and a wall thickness of $6.22 \mathrm{~mm}$.

A special loading system was developed to simulate the traffic loads from the front and rear wheels of a truck during the centrifuge tests. The system consists of two air pressure cylinders (Fig. 3), which are fixed in a steel plate bolted on the top of the strongbox. The air pressure inside of the cylinder could be adjusted during the centrifuge test in flight to simulate different magnitudes of traffic load.

During a full-scale test, a load $F_{p}$ is applied on an area with a length of $A_{p}$ and a width of $B_{p}$, while during the centrifuge test a load $F_{m}$ is applied on a loading plate with dimensions of $\frac{A_{p}}{N}$ and $\frac{B_{p}}{N}$. Therefore, the similarity of stresses beneath the loading plates leads to equation (2):

$$
\frac{F_{p}}{A_{p} \times B_{p}}=\frac{F_{m}}{\frac{A_{p}}{N} \times \frac{B_{p}}{N}}
$$

a)
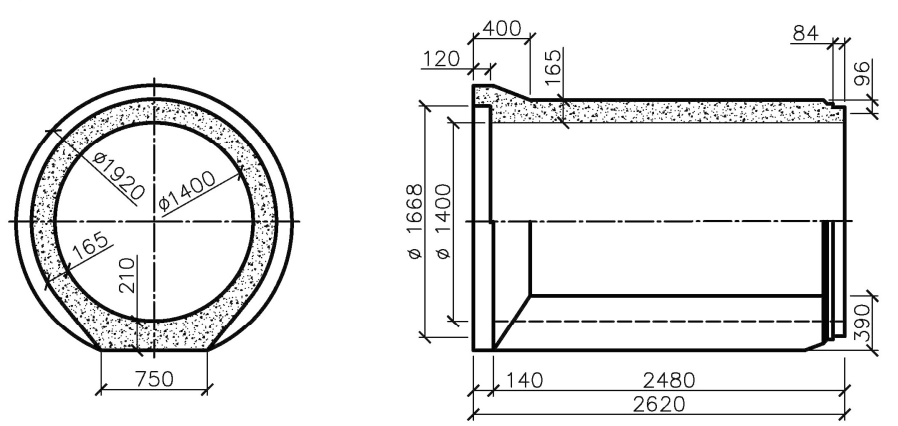

c)

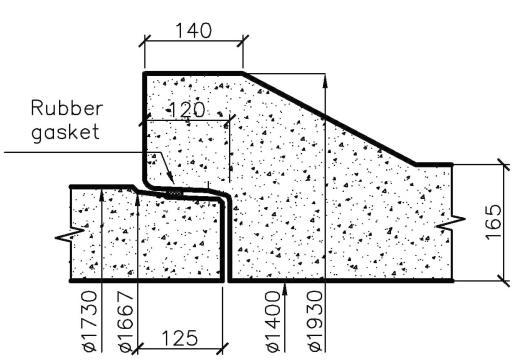

Fig. 2. The prototype of the reinforced concrete pipe: cross (a) and longitudinal (b) sections, bell - and - spigot pipe joint (c). (All dimensions in $\mathbf{~ m m}$ ) 
a)

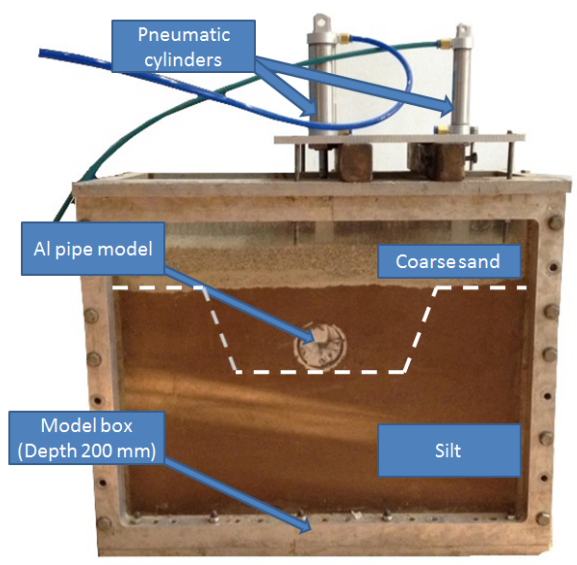

END ELEVATION

END ELEVATION
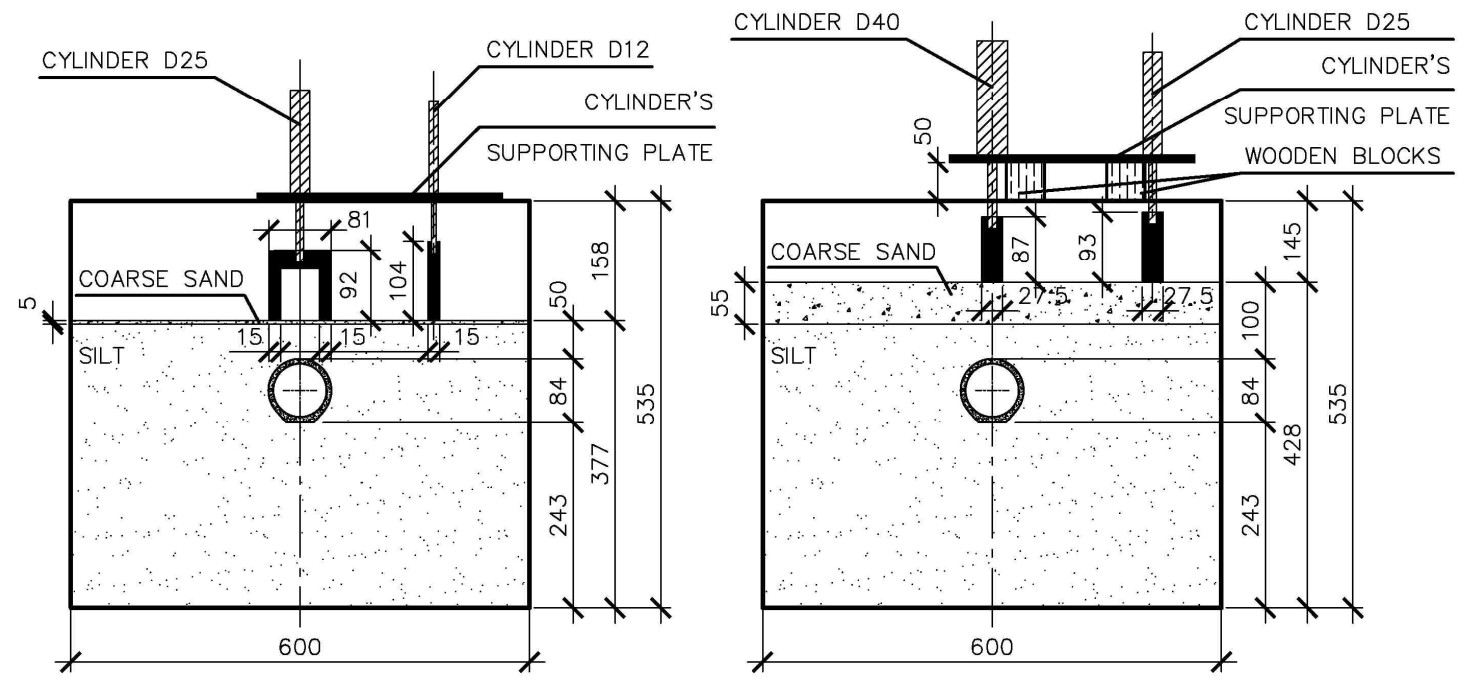

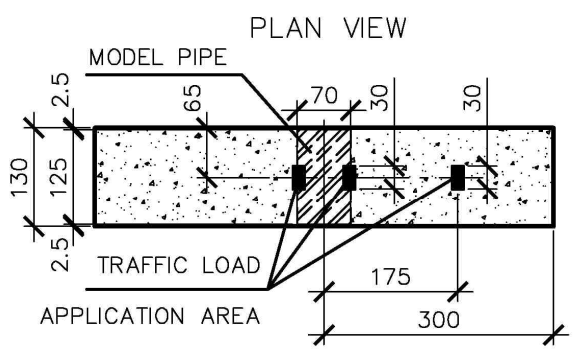

b)

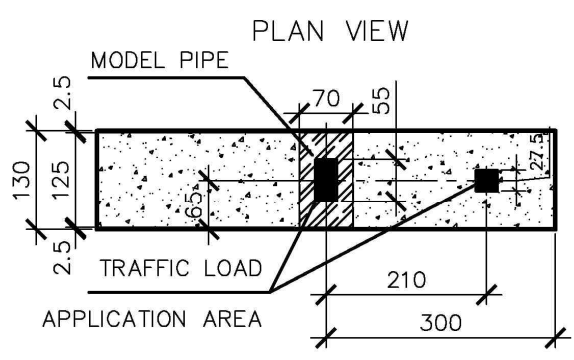

c)

Fig. 3. The centrifuge strongbox with pipe model and loading system: (a) photographic view, (b) schematic views for Test 7 with medium truck loading and soil cover depth of $1 \mathrm{~m}$, (c) schematic views for Test 4 with heavy truck loading and soil cover depth of $2 \mathrm{~m}$

Hence, a surface load $F_{m}$ applied during the centrifuge tests should equal to the prototype load $F_{p}$ divided by $N^{2}$ :

$$
F_{m}=\frac{F_{p}}{N^{2}}
$$

Two different types of traffic load were applied during the tests, which correspond to a heavy truck and a medium truck with a maximum weight of $850 \mathrm{kN}$ and $252 \mathrm{kN}$ respectively. Figure 4 and Table 1 give the prototype traffic load parameters for the simulated trucks.

\subsection{Instrumentation and measurements}

In total, 8 pairs of strain gauges were installed at eight different locations on the pipe: crown, shoulder, springline, haunch and invert (Fig. 5). These strain gauges were BE120-05AA type electric resistance strain gauges, the readings of which were used to derive the bending moments of the pipe wall. It was noticed that the resistance of the strain gauges would 
AXES LOADS

$566.7 \mathrm{kN} \quad 283.4 \mathrm{kN}$

AXES LOADS

$95 \mathrm{kN} 95 \mathrm{kN} \quad 62 \mathrm{kN}$
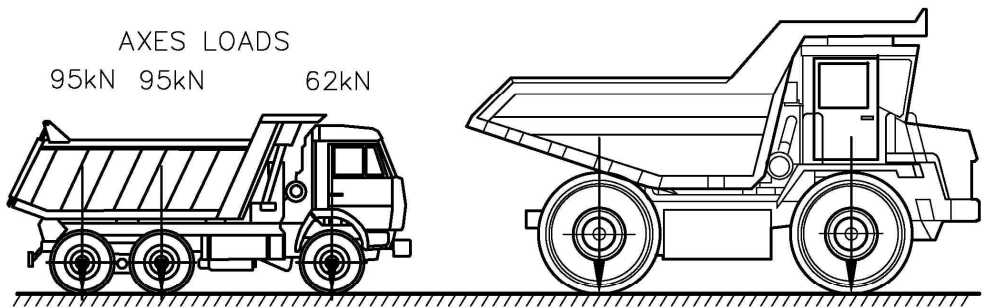

PLAN VIEW

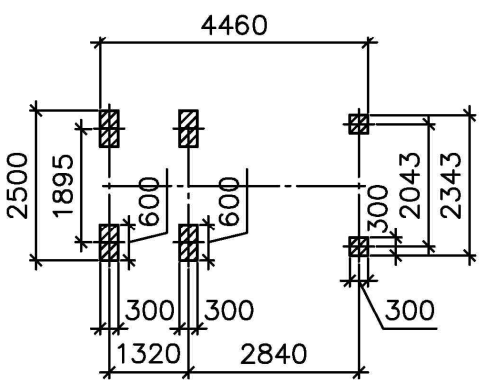

PLAN VIEW

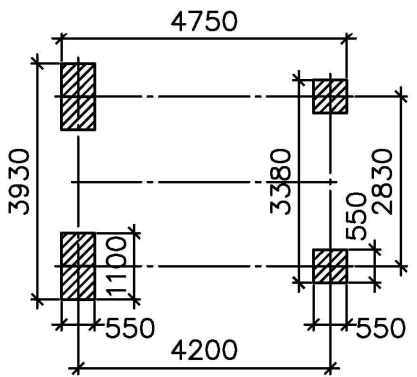

Fig. 4. The geometrical parameters for the traffic loads. (All dimensions in $\mathrm{mm}$ )

Prototype traffic load parameters

\begin{tabular}{|c|c|c|c|c|c|c|c|}
\hline & Total weight & \multicolumn{2}{|c|}{ Axial loads $(\mathrm{kN})$} & \multicolumn{2}{c|}{ Wheel loads $(\mathrm{kN})$} & \multicolumn{2}{c|}{ Pressure $\left(\mathrm{kN} / \mathrm{m}^{2}\right)$} \\
\cline { 3 - 8 } & $(\mathrm{kN})$ & Front axis & Rear axis & Front wheel & Rear wheel & Front wheel & Rear wheel \\
\hline $\begin{array}{c}\text { Medium } \\
\text { truck }\end{array}$ & 252 & 62 & 95 & 31 & 47.5 & 344.4 & 263.9 \\
\hline Heavy truck & 850 & 283.3 & 566.7 & 141.65 & 283.35 & 468.3 & 468.3 \\
\hline
\end{tabular}

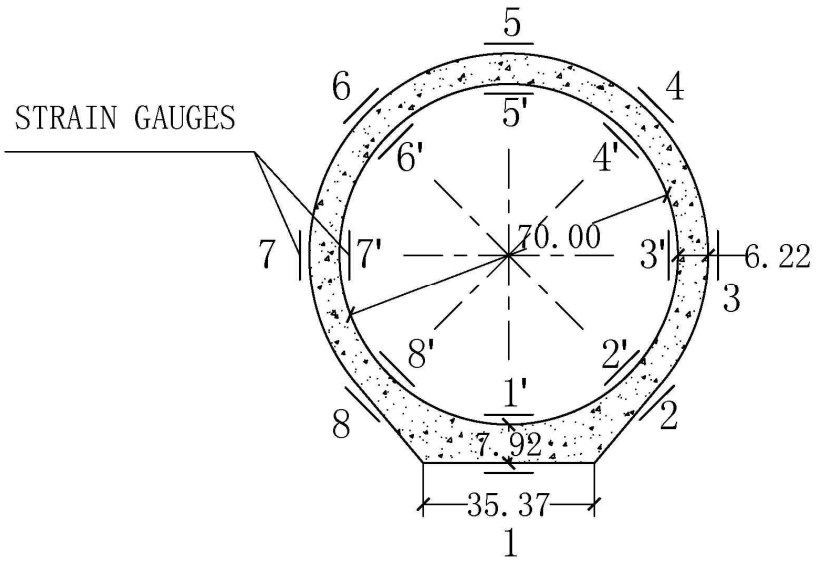

(a)

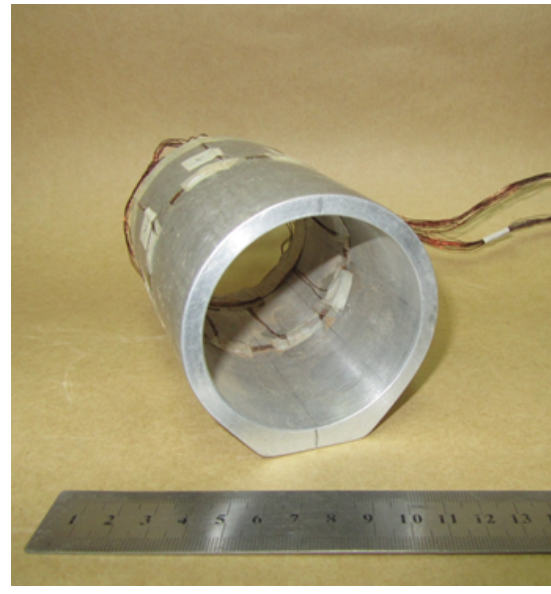

(b)

Fig. 5. The aluminum pipe model (a) and locations of strain monitor points (b)

change not only in response to applied strains, but also to temperature variations. Therefore a temperature compensation system was developed to minimize the sensitivity of strain gauges to temperature variations. The strain gauges used for the temperature compensation system were installed on an unstrained aluminum plate. During the test, the plate was kept at the same thermal conditions as the aluminum pipe model, so that the temperature effects on the strain measurement could be balanced. All strain gauges were connected to the 32-channel data acquisition system, which took readings once every second. 


\section{Теория расчета строительных конструкций}

\subsection{Model preparation}

Figure 6 shows the geometrical parameters for each test (dimension in prototype scale) with different soil cover depths. The bottom width of the trench was $4.93 \mathrm{~m}$, and the sides were inclined at an angle of 70 degrees to the horizon.

The original ground and the trench backfills were silt soil, which has similar properties to the soil in the full-scale test. The particle size distribution of the silt soil is shown in Fig. 7. The plastic limit and liquid limit of the silt soil are $14.6 \%$ and $29.3 \%$ respectively, and the specific gravity $G_{s}$ is 2.71 . The dry density was $\gamma_{\mathrm{d}}=1.82 \mathrm{~g} / \mathrm{cm}^{3}$ and the water content was $12 \%$, which was the same as the field conditions.

In four tests (Tests 2, 4, 6, and 8), a 1-m embankment was simulated using very dense coarse sand, the particle size distribution of which is also shown in Fig. 7 with a typical $\mathrm{D}_{50}$ of $3 \mathrm{~mm}$. The density of the sand used in the tests was $\gamma=1.90 \mathrm{~g} / \mathrm{cm}^{3}$ with a water content less than 0.5 percent. The maximum and minimum void ratios were found to be $\mathrm{e}_{\max }=0.986$ and $\mathrm{e}_{\min }=0.443$. The specific gravity of

Test 1

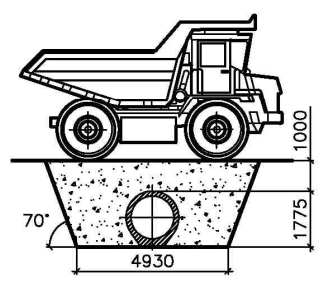

Test 2

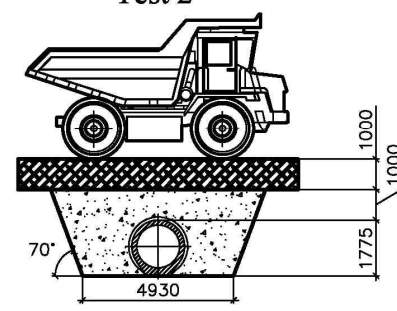

Embankment

Trench
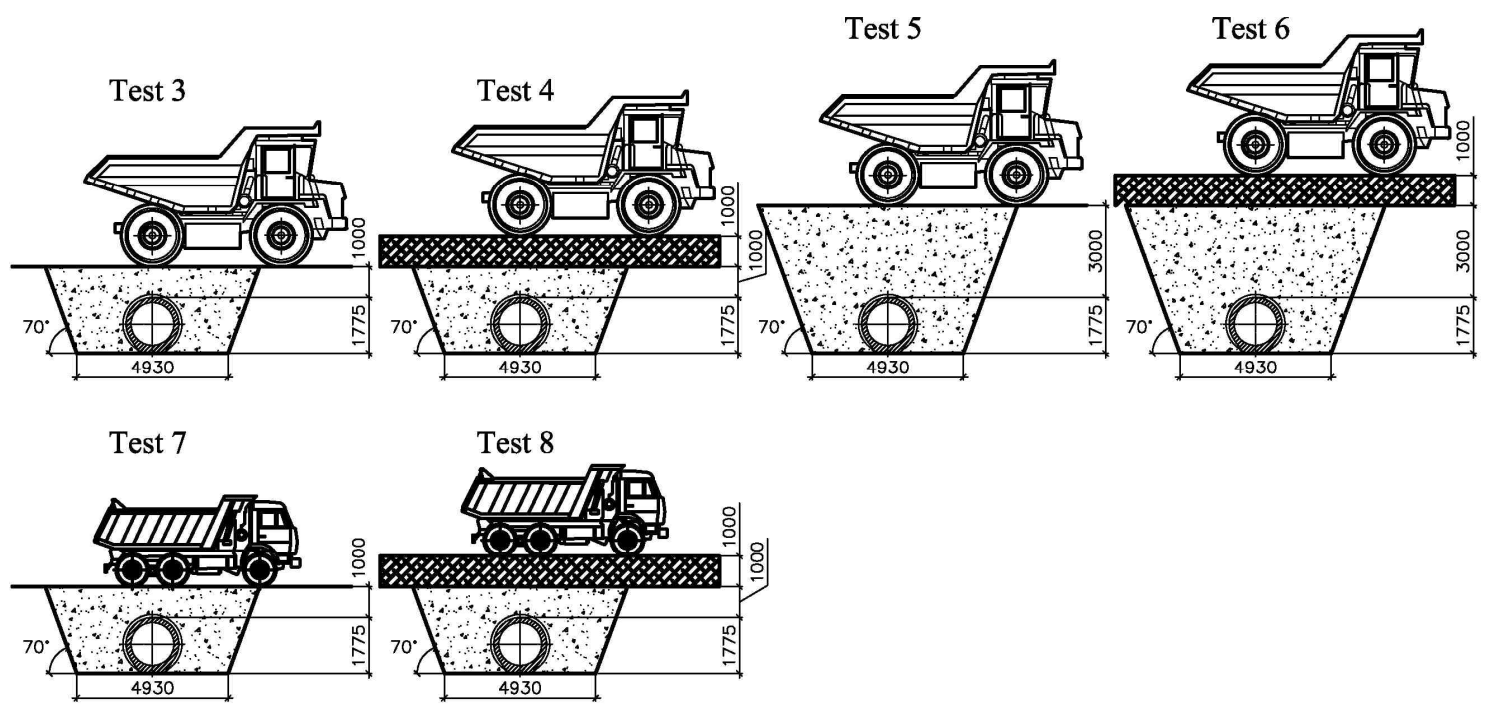

Fig. 6. Schemes of centrifuge tests

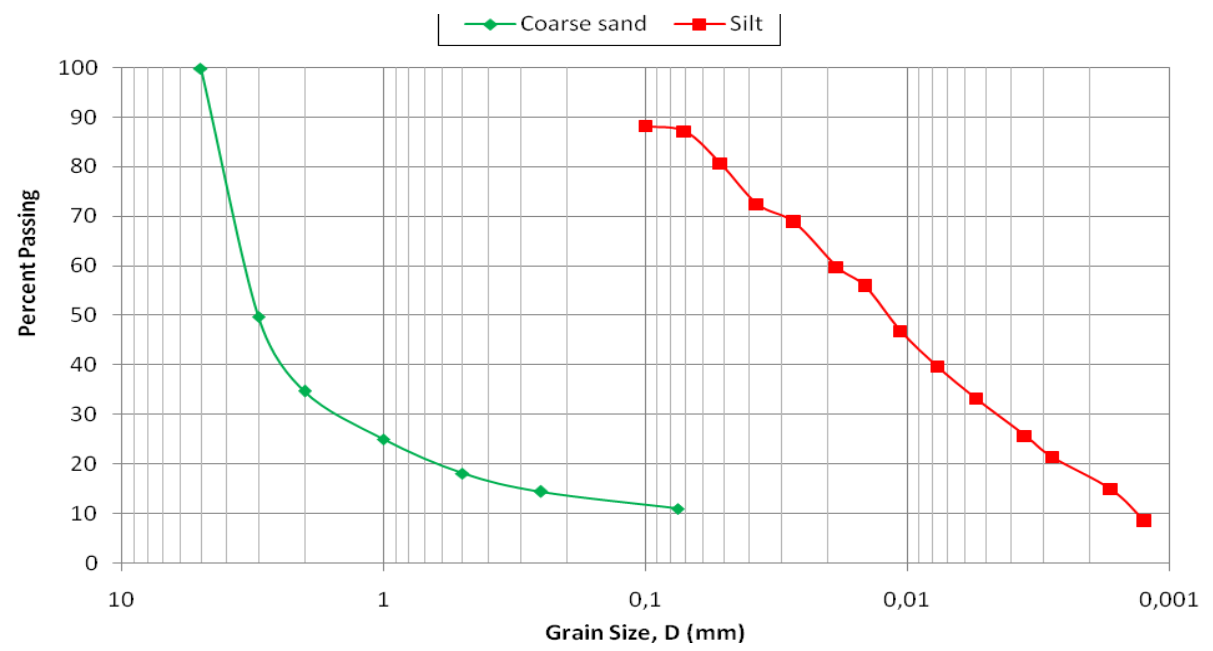

Fig. 7. The particle - size distribution of model materials (ASTM D422) 
the sand solids is $G_{s}=2.77$. A relative density $D_{r}$ of 0.963 was achieved during the tests.

The silt soil was compacted by $25 \mathrm{~mm}$ thick layers until the desired model height was achieved, followed by forming the trench by removing the redundant soil. After the pipe model was installed, the trench was backfilled with the same silt soil. The sides of the strongbox were lubricated with silicon grease in order to minimize friction.

There is a small gap of $2.5 \mathrm{~mm}$ between each end of the model pipe and the wall of the strong box. The gap was sealed with thick ointment strips along the edge of the pipe end, which allowed the pipe to deform freely with minimal end friction while preventing soil particles from falling into the gap.

\subsection{Test program and procedure}

In total, eight geotechnical centrifuge tests were carried out (Fig. 6 and Table 2). As described in the previous section, the most severe loading conditions for the pipe occurred due to heavy construction traffic traversing the pipes during the construction process [7]. Much heavier trucks are becoming increasingly popular, particularly due to their high efficiency in moving large amount of soil debris. Therefore, a heavy truck with a maximum load of $850 \mathrm{kN}$ was simulated in the majority of the centrifuge testing program (Test 1 6). The prototype of this heavy truck is BelAZ 7547, which is similar to an American Caterpillar 772 off-highway truck. Such heavy trucks are now widely used for earthmoving work on construction sites and quarries. Furthermore, a medium truck with a maximum load of $252 \mathrm{kN}$ was also studied in two centrifuge tests (Tests 7 8).

Usually the pipeline would be buried at a shallow depth, e.g. 1 2 m. However, in some situations the pipeline has to be buried at a much deeper location. For example, pipes are required to be installed below the depth of seasonally frozen ground in order to avoid the influence of soil heaving. In Siberia, the depth of seasonally frozen ground is $2.64 \mathrm{~m}$ [30]. In the northern areas of China, the design depth for seasonally frozen ground is $2.6 \mathrm{~m}$. Therefore, different soil cover depths were investigated, which varies from $1 \mathrm{~m}$ to $4 \mathrm{~m}$.

The horizontal position of the traffic vehicle was also studied, with the pipe being located either between the front and rear axis, or directly below the rear axis. below:

The procedure for each test is described as

1. The centrifuge model was prepared, including the model pipe with measurement gauges, the soils compaction, the loading system installation, and positioning the strong box on the centrifuge cradle.

2. The acceleration was increased gradually to $20 \mathrm{~g}$.

3. The strains induced by the weight of the soil cover were recorded.

4. The traffic load was increased by 4 steps, which correspond to $25 \%, 50 \%, 75 \%$ and $100 \%$ of the maximum vehicle load. Readings were taken at each step.

\section{Full-scale tests}

In addition to the geotechnical centrifuge testing program, a series of full-scale tests (see Figure 8a) were performed on reinforced concrete pipes with an inner diameter of $1400 \mathrm{~mm}$ with a soil cover depth of $1 \mathrm{~m}$ and $2 \mathrm{~m} \mathrm{[31].}$

Three kinds of vehicles were used for simulating different traffic loads, including a car, a medium truck, and a heavy truck. The weight of the medium truck and the heavy truck in the full-scale tests was $252 \mathrm{kN}$ and $850 \mathrm{kN}$, respectively, which are identical to those adopted in centrifuge tests. A $55-\mathrm{m}$ long pipeline was buried in a trench, the geometrical parameters of which were the same as those for the centrifuge tests (Fig. 6). After completing the tests with a soil cover of $1 \mathrm{~m}$, a $1 \mathrm{~m}$-thick embankment was constructed on the ground level, so that a 2-m soil cover was achieved.

During the test, the truck was moving slowly while traversing the pipeline. The stress-strain states of two adjacent pipes were monitored during the tests. For each pipe, strain gauges were installed at three cross sections: near the spigot ( $\mathrm{A}$ and $\mathrm{D})$, at the middle ( $\mathrm{B}$ and $\mathrm{E})$, and near the bell $(\mathrm{C}$ and $\mathrm{F})$, as shown in Fig. 8b. The highest strains were recorded in the middle cross sections $\mathrm{B}$, which located exactly below the track wheel, so the strain gauges were installed in the same cross section during the centrifuge test. There were 11 pairs of strain gauges at each cross section. During the test, the bending moments were recorded when the truck was at different positions relative to the pipeline axis.

Details of each centrifuge test

\begin{tabular}{|c|c|c|c|c|}
\hline Test № & $\begin{array}{c}\text { Soil cover depth } \\
(\mathrm{m})\end{array}$ & $\begin{array}{c}\text { Type } \\
\text { of traffic vehicle }\end{array}$ & $\begin{array}{c}\text { Position } \\
\text { of traffic vehicle }\end{array}$ & $\begin{array}{c}\text { Maximum applied traffic load } \\
\text { (scaled to prototype) }(\mathrm{kN})\end{array}$ \\
\hline 1 & 1 & Heavy truck & Pipe between two axes & 850 \\
\hline 2 & 2 & Heavy truck & Pipe between two axes & 850 \\
\hline 3 & 1 & Heavy truck & Rear axis above the pipe & 850 \\
\hline 4 & 2 & Heavy truck & Rear axis above the pipe & 850 \\
\hline 5 & 3 & Heavy truck & Rear axis above the pipe & 850 \\
\hline 6 & 4 & Heavy truck & Rear axis above the pipe & 252 \\
\hline 7 & 1 & Medium truck & Rear axis above the pipe & 252 \\
\hline 8 & 2 & Medium truck & Rear axis above the pipe & \\
\hline
\end{tabular}




\section{Теория расчета строительных конструкций}

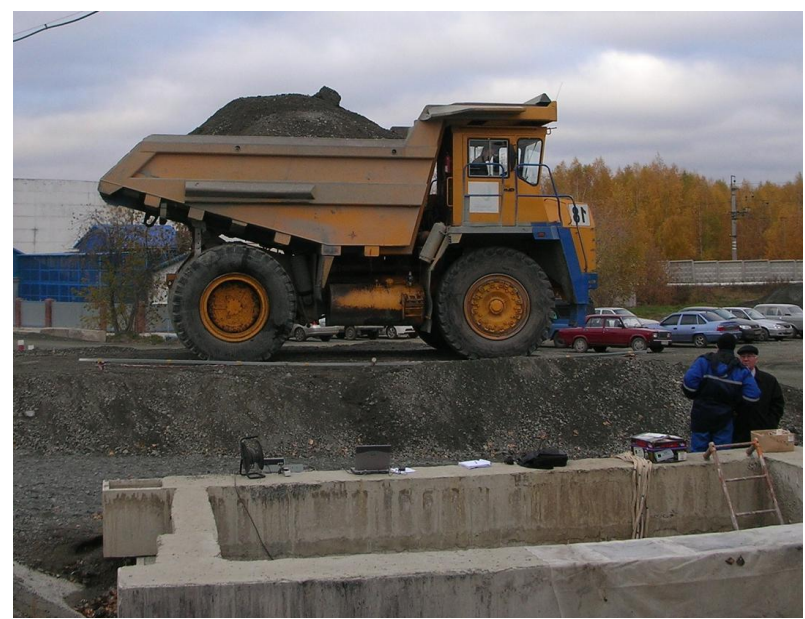

a)

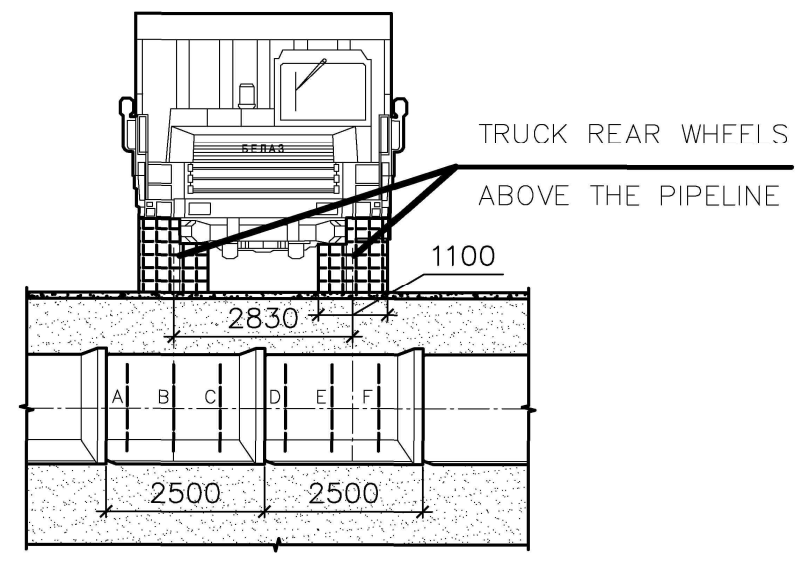

b)

Fig. 8. The full - scale testing of the underground pipeline using a heavy truck. Photographic (a) and schematic (b) views

Because the test conditions of the centrifuge tests were fairly similar to those of the full-scale test, a direct comparison becomes possible between the results of those two independent test methods, which will be discussed in the next section.

\section{Results and Discussion}

4.1. Comparison of the results from full - scale tests and centrifuge tests

The bending moments around the pipe wall during the centrifuge testing were compared with those measured at the middle cross section (Section B in Fig. 8b) in the full-scale field testing. Figures 9 a \& b show the results of the heavy truck with a soil cover depth of $1 \mathrm{~m}$ and $2 \mathrm{~m}$ (Centrifuge Tests 3 and 4). It can be seen that the centrifuge testing results compare reasonably well with the full-scale testing results, with a maximum difference of about $18 \%$ for Fig. 9a and $11 \%$ for Fig. 9b. Similar observations can be made in Fig. 10, in which a medium truck load is investigated. It is interesting to note that despite the small difference, the measured bending moments in the centrifuge tests are somewhat larger than those at the corresponding locations in the full scale tests, which indicates that conservative results were obtained in the centrifuge tests.

\subsection{The influence of traffic load position}

The position of the traffic load relative to the pipe is one of the most critical parameters for performance evaluation of large diameter reinforced concrete pipes. Centrifuge Tests 1 and 3 (see Fig. 6) were performed to study the influence of traffic load positions. In both tests, the soil cover depth is $1 \mathrm{~m}$. In Test 1 , the pipe is located below the middle point between the front axis and the rear axis, while in Test 2 the pipe was located exactly below the rear (the heaviest) axis of the heavy truck. The test results are presented in Fig. 11.
At the beginning of the tests when no traffic load was applied at the soil surface, the bending moments at the crown of the pipe were the same, which were induced by the weight of the 1-m cover soil. However, when the traffic load was applied with an increment of $25 \%$ of the maximum truck weight at each step, a significant difference was observed between those two tests. On average, the bending moment at the pipe crown in Test 3 was found to be two times higher than that in Test 1. It appears that the pipe would experience the most unfavorable conditions when the heaviest axis of the traffic vehicle is located exactly above the pipe crown. In the full-scale test shown in Figure 8, the bending moment was also found to reach its maximum value when the rear truck wheel was located exactly above Cross Section B (at the middle of the pipe).

Similar observations were made for Tests 2 and 4 , in which the soil cover depth was $2 \mathrm{~m}$. Therefore, all other centrifuge tests were performed with the pipe located directly below the rear axis of the truck.

\subsection{The initial bending moments due to soil cover weight}

The initial strains in the aluminum pipe model due to the weight of the cover soil were measured before any traffic load was applied in the centrifuge tests. The bending moments at different locations around the pipe from Tests 3 6 are derived, as shown on Fig. 12. When the soil cover depth was increased from $1 \mathrm{~m}$ to $4 \mathrm{~m}$, the initial bending moments were increased accordingly. For a 1-m increment in the cover soil depth, the maximum bending moment at the pipe crown was increased at a constant rate by about $1200 \mathrm{~N} \cdot \mathrm{m} / \mathrm{m}$, which is about $60 \%$ of the corresponding value with a soil cover depth of $1 \mathrm{~m}$. Therefore a deeper soil cover would lead to a higher initial stresses. 


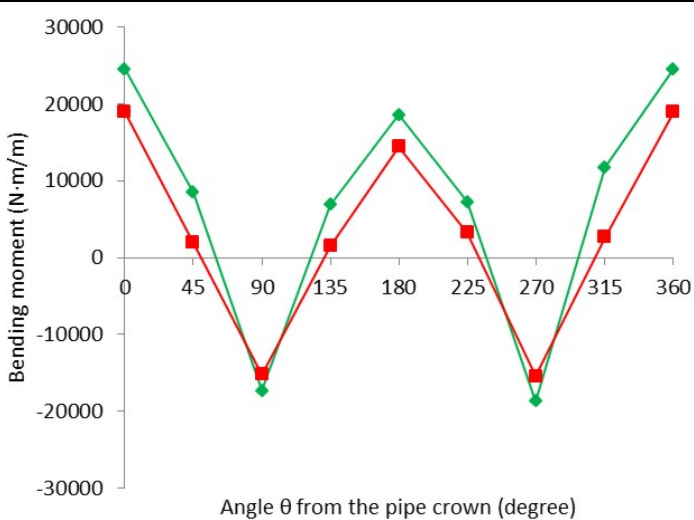

a)

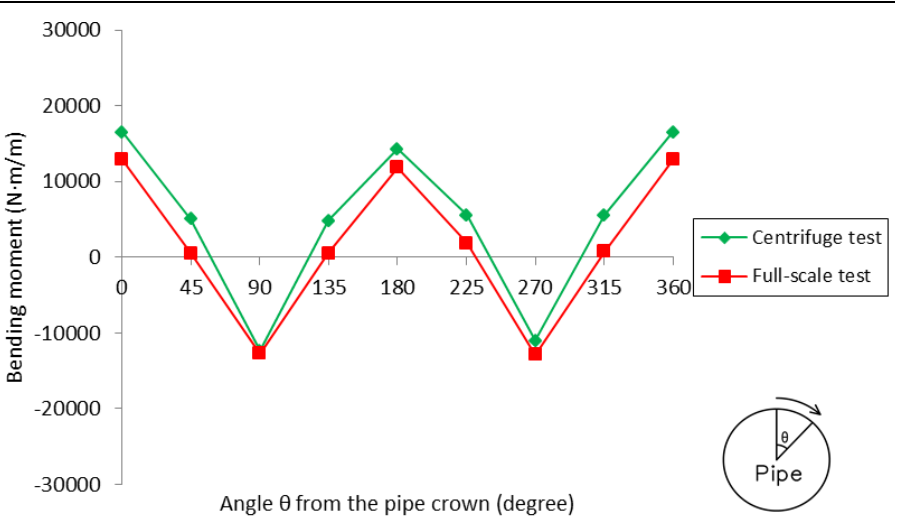

b)

Fig. 9. Comparison of centrifuge Tests 3 and 4 with simular full - scale test data:

(a) soil cover depth of $1 \mathrm{~m}$; (b) soil cover depth of $2 \mathrm{~m}$

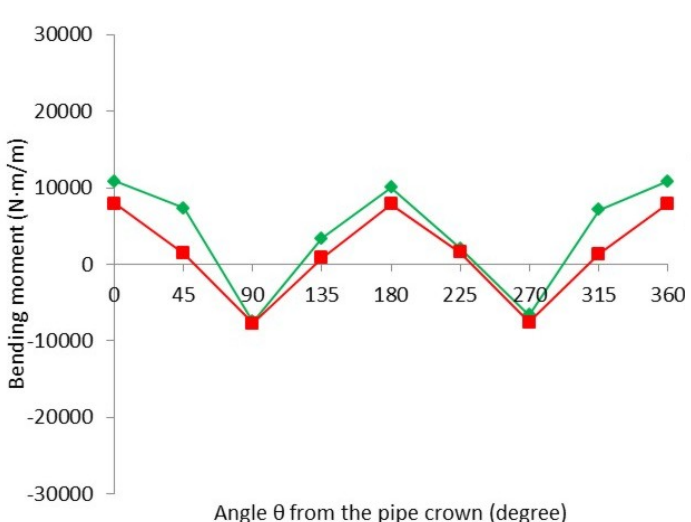

a)

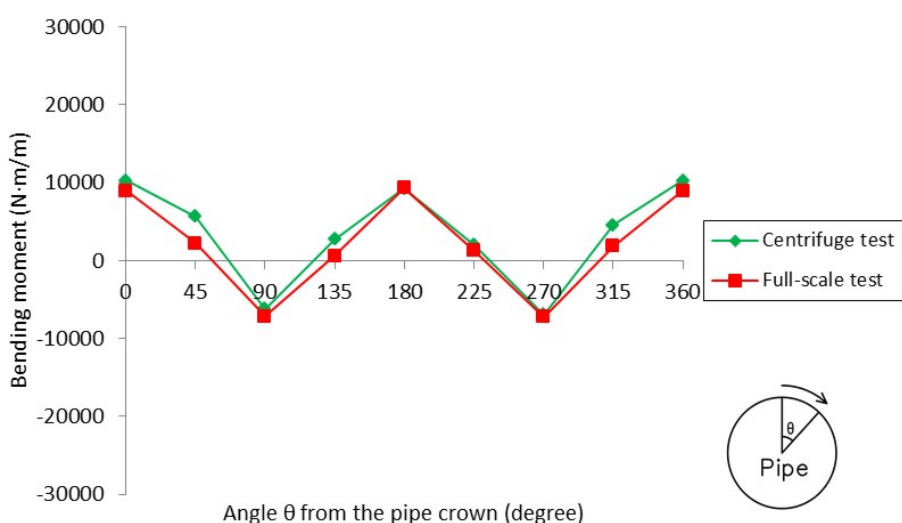

b)

Fig. 10. Comparison of centrifuge Tests 7 and 8 and simular full - scale test data:

(a) soil cover depth of $1 \mathrm{~m}$; (b) soil cover depth of $2 \mathrm{~m}$

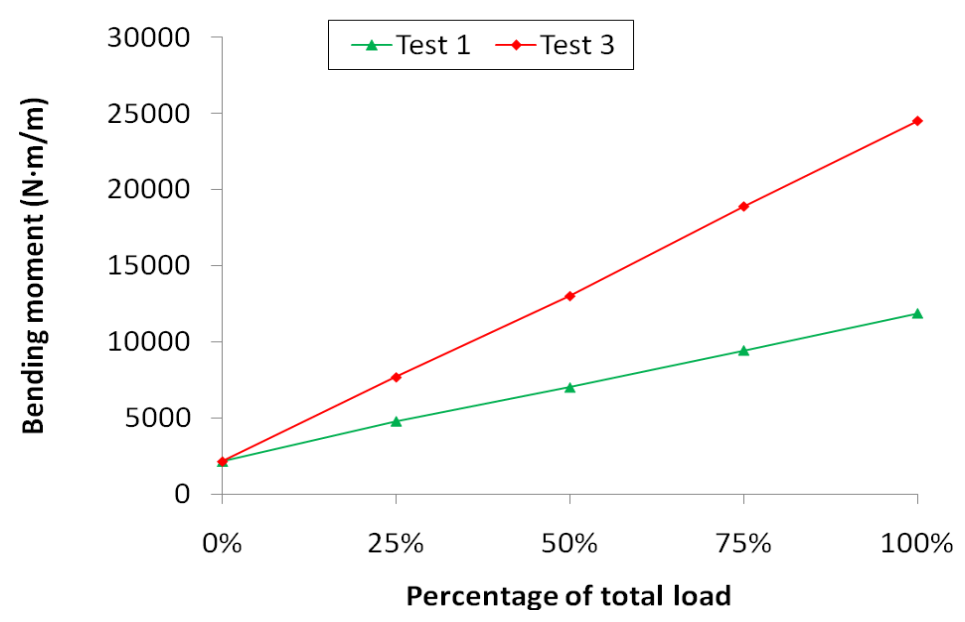

Fig. 11. Comparison of differing truck positions' influence on the pipe

4.4. The influence of soil cover depth on the pipe stress-strain states

The rear axis of a heavy truck (with total axis load of $850 \mathrm{kN}$ ) was located exactly above the pipe in Tests 3, 4, 5 and 6. In those four tests, only the soil cover depth varied from $1 \mathrm{~m}$ to $4 \mathrm{~m}$ while all the other testing conditions remained the same, as shown in Fig. 6. During each test, the traffic load was increased by four equal steps: $25 \%, 50 \%, 75 \%$ and $100 \%$, as describe in the previous section.

Fig. 13 presents the bending moments around the pipe at different loading stages from those four 


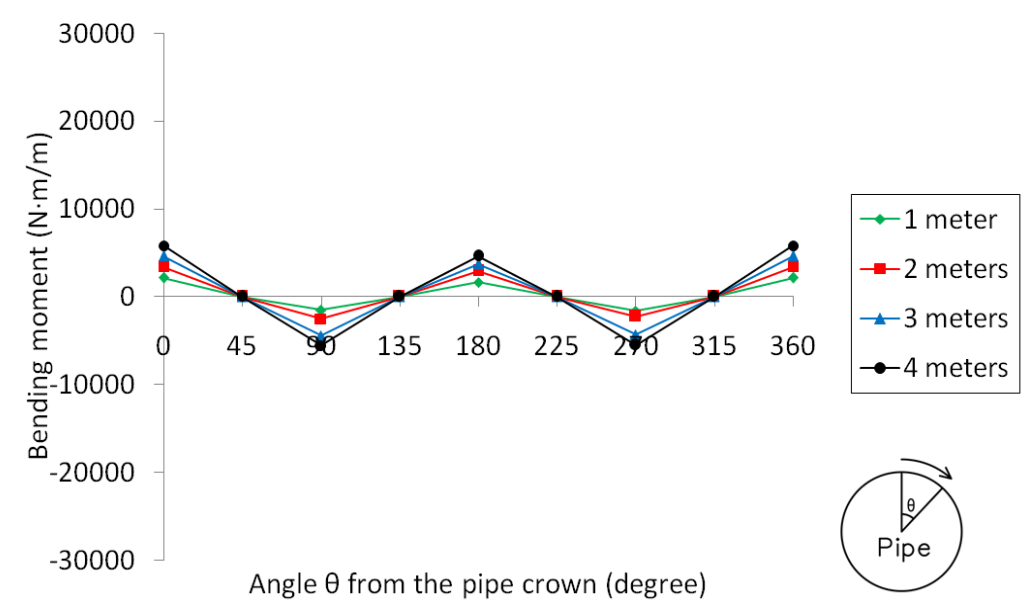

Fig. 12. Comparison of soil cover depth influence on the pipe (Tests 3-6)

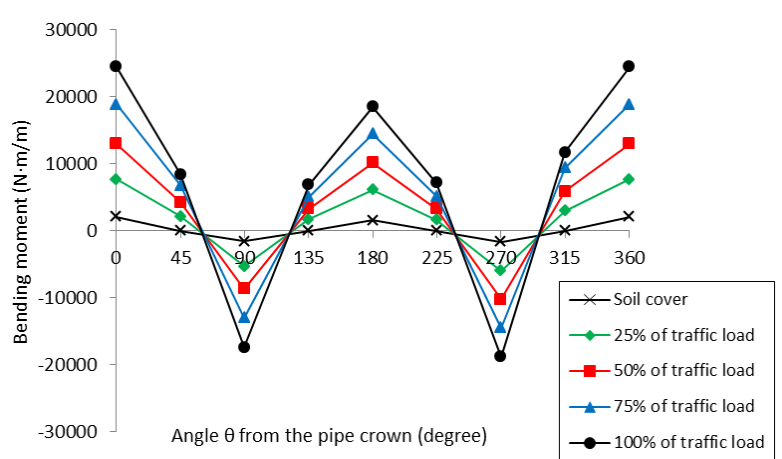

a)

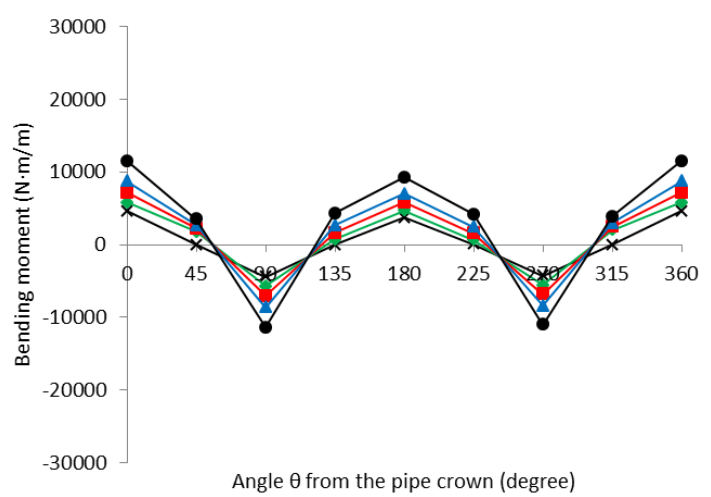

c)

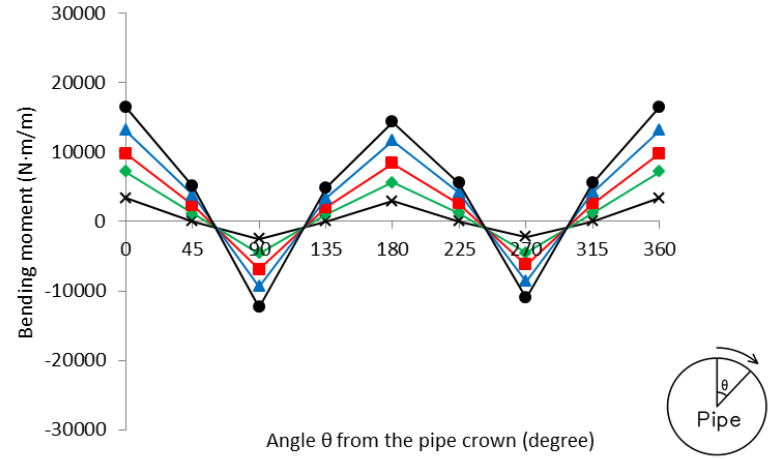

b)

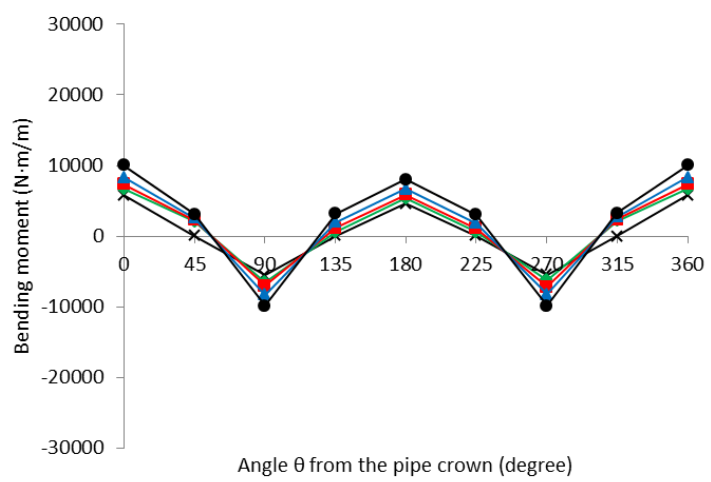

d)

Fig. 13. Comparison of combined influence of soil cover depth and heavy truck load on the pipe. Soil cover depths: $1 \mathrm{~m} \mathrm{(a);} 2 \mathrm{~m}$ (b); $3 \mathrm{~m}$ (c) and $4 \mathrm{~m}$ (d)

centrifuge tests. The initial bending moment, which was induced by the weight of soil (e.g. $0 \%$ of traffic loading), was increased with the depth of soil cover, as described in Section 4.3.

However, the bending moment increment induced by additional traffic loading was found to decrease with the soil cover depth. At each step, the traffic load was increased by $25 \%$. When the soil cover depth was $1 \mathrm{~m}$ (Tests 3 ), an $25 \%$ increment in traffic load resulted in an increment of the bending moment at the pipe crown by approximately $5600 \mathrm{~N} \cdot \mathrm{m} / \mathrm{m}$. However, for a soil cover depth of $3 \mathrm{~m}$ (Tests 5), the bending moment at the pipe crown was increased by only $1700 \mathrm{~N} \cdot \mathrm{m} / \mathrm{m}$, or nearly 3 times less, for an equal traffic load increment.

As a result, the final bending moment under $100 \%$ of the heavy truck load was found to decrease as the depth of soil cover increases. The final bending moment at the pipe crown was $24516 \mathrm{~N} \cdot \mathrm{m} / \mathrm{m}, 16493 \mathrm{~N} \cdot \mathrm{m} / \mathrm{m}$, $11482 \mathrm{~N} \cdot \mathrm{m} / \mathrm{m}$ and $10069 \mathrm{~N} \cdot \mathrm{m} / \mathrm{m}$ for soil cover depths of 
$1 \mathrm{~m}, 2 \mathrm{~m}, 3 \mathrm{~m}$, and $4 \mathrm{~m}$, respectively. The final bending moment was decreased by more than two times when the soil cover depth increased from $1 \mathrm{~m}$ to $3 \mathrm{~m}$. Thus the effect of the heavy truck load application was maximized at a shallow depth, and decreased sharply with increasing soil cover depth.

It is also observed that the curve of the initial bending moment vs. the angle is approximately symmetrical along the $\mathrm{x}$-axis for all four soil cover depths varying from $1 \mathrm{~m}$ to $4 \mathrm{~m}$ (also see Fig. 12), e.g. the bending moment is around zero at the pipe shoulders and haunches $\left(45^{\circ}, 135^{\circ}, 225^{\circ}\right.$ and $315^{\circ}$ ) while it is slightly higher at the crown than the invert. However, the curves of final bending moment vs. angle become highly unsymmetrical for shallower cover depths (e.g., $1 \mathrm{~m}$ and $2 \mathrm{~m}$ ), with considerable bending moments appearing at the shoulders and haunches, with a final bending moment at the crown being much higher than that at the invert. In contrast, the final curves still remain largely symmetrical for deeper cover depth (e.g., $3 \mathrm{~m}$ and $4 \mathrm{~m}$ ), despite some bending moments at the pipe shoulders and haunches.

\subsection{The separated influence of traffic load and soil cover weight}

The data from Tests $3 \sim 6$ is further plotted in Fig. 14 to study the separated influence of the traffic load and soil cover weight, e.g. the bending moment induced only by traffic loading and that induced only by soil cover weight. The bending moment at the pipe crown was analyzed, which was the most stressed position around the cross section.

When the soil cover depth was increased from 1 to $4 \mathrm{~m}$, the initial bending moment induced by the soil weight was increased linearly by over two times, from $2150 \mathrm{~N} \cdot \mathrm{m} / \mathrm{m}$ to $5790 \mathrm{~N} \cdot \mathrm{m} / \mathrm{m}$, while the bending moment induced by the full traffic load was decreased by over 5 times from $22366 \mathrm{~N} \cdot \mathrm{m} / \mathrm{m}$ to $4279 \mathrm{~N} \cdot \mathrm{m} / \mathrm{m}$.

It can be also found in Figure 14 that when the soil

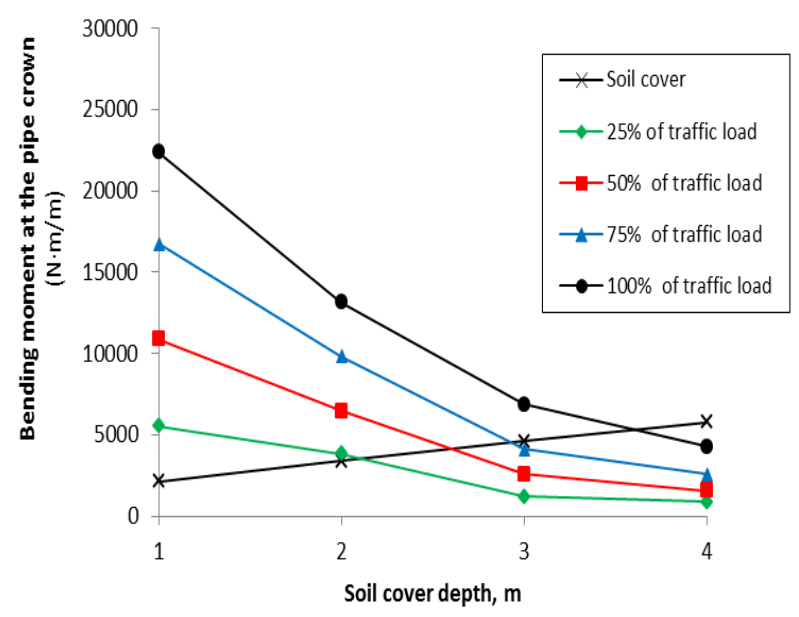

Fig. 14. Comparison of soil cover depth and heavy truck load separated influence on the pipe cover depth is $1 \mathrm{~m}$, the influence of the traffic load was about 10 times higher than that induced by soil cover weight. The bending moment induced by the soil cover weight becomes equal to that induced by a heavy traffic load at a soil cover depth of $3.6 \mathrm{~m}$. For deeper soil cover depth, the bending moment induced by the soil cover weight would exceed that induced by the heavy truck load, which was $850 \mathrm{kN}$ in this investigation.

It is noted that even at a soil cover depth of $4 \mathrm{~m}$, the bending moment induced by the heavy truck $(850 \mathrm{kN})$ is $4279 \mathrm{~N} \cdot \mathrm{m} / \mathrm{m}$, which is significant compared with the bending moment $5790 \mathrm{~N} \cdot \mathrm{m} / \mathrm{m}$ induced by the soil cover weight. In contrast, the ACPA suggests that the live loads for soil cover depth of $3.05 \mathrm{~m}(10 \mathrm{ft})$ or more are insignificant [32], with the AASHTO HS-20 alternative loading being considered. Such a vehicle has a total weight of $320 \mathrm{kN}$ and two rear axes with a wide distance of $4.3 \mathrm{~m} \sim 9.1 \mathrm{~m}$, and the weight for each rear axis is $142 \mathrm{kN}$. Therefore, the load for each axis is approximately $25 \%$ of the heavy truck rear axis load in this study. As shown in Fig. 14, though the bending moment induced by $25 \%$ heavy truck load is indeed small when the soil cover depth is $4 \mathrm{~m}$, it becomes significant and cannot be ignored at a $100 \%$ heavy truck load, compared with the bending moment induced by the soil cover weight.

Similar observations can be made in Fig. 15, in which a medium truck was simulated with a soil cover depth of $1 \mathrm{~m}$ and $2 \mathrm{~m}$ (Tests 7 and 8). Therefore, a deeper soil cover depth would reduce the influence of traffic load significantly, despite of an increased influence of soil cover weight.

\subsection{The combined influence of traffic load and soil cover}

Figure 16 illustrates the development of the bending moment at the pipe crown in Tests $3 \sim 6$, which is plotted against the percentage of traffic load. For example, $0 \%$ means that no traffic load was

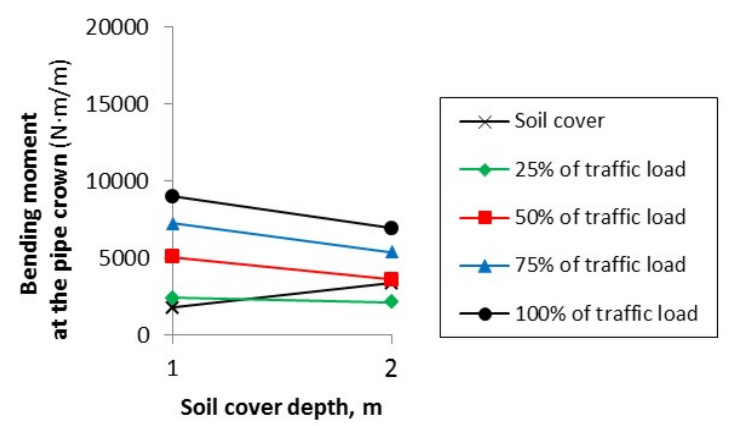

Fig. 15. Comparison of soil cover depth and medium truck load separated influence on the pipe 


\section{Теория расчета строительных конструкций}

applied; thus, only the soil weight was acting on the pipeline. For a shallower soil cover, the curve starts from a lower initial bending moment, but with a steeper slope, which reflects the more significant influence of traffic loading. In contrast, for deeper soil cover, the curve starts from a higher initial bending moment, but with a less steep slope, indicating a reduced influence of traffic loading. It is also observed that the bending moment increased approximately linearly with the traffic load for a shallower soil cover, while the relationship becomes highly nonlinear for a deeper soil cover.

The graphs in Fig. 17 show the results of Tests 7 and 8, in which a medium truck load was simulated with a soil cover depth of $1 \mathrm{~m}$ and $2 \mathrm{~m}$. Although the initial bending moment in Test 8 (with a $2 \mathrm{~m}$ soil cover) is almost two times higher than that in Test 7, the final bending moments are almost the same. It can be seen from Figure 15 that the bending moments only induced by full traffic load is $9037 \mathrm{~N} \cdot \mathrm{m} / \mathrm{m}$ for Test 7 and $6949 \mathrm{~N} \cdot \mathrm{m} / \mathrm{m}$ for Test 8. As the soil cover weight is a dead load while the traffic loading is a live load, a higher bending moment induced by traffic loading would be more unfavorable, particularly due to its cyclic characteristic [33]. Therefore, even though the final bending moments are similar, as shown in Figure 17 , a deeper soil cover would be preferred.

\subsection{Comparison with current calculation methods}

The centrifuge tests results of large diameter pipes subjected to heavy truck loading are compared with calculated results, which are obtained using several widely adopted design methods for underground pipeline design.

For the bending moment induced by the soil overburden (dead load), two different calculation methods are used: the traditional Marston-Spangler method and the method described in the American Concrete Pipe Association Design Manual, further mentioned as ACPA method [32]. The comparison of the results is presented in Table 3 . Both methods give a conservative prediction for the bending moments at the crown of the large diameter pipe, particularly for the ACPA method, which is more than two times higher than the test results for all soil cover depths. In contrast, the Marston-Spangler method gives a marginally higher bending moment at a shallow soil cover depth of $1 \mathrm{~m}$. McAffee and Valsangkar [34] also found that the Marston-Spangler method is conservative in designing induced trench culverts.

For the bending moment induced by the heavy traffic weight (live load), the Boussinesq method [35] and the method described in the American Concrete Pipe Association Design Manual (ACPA method) are used. The comparison of the results is presented in Table 4.

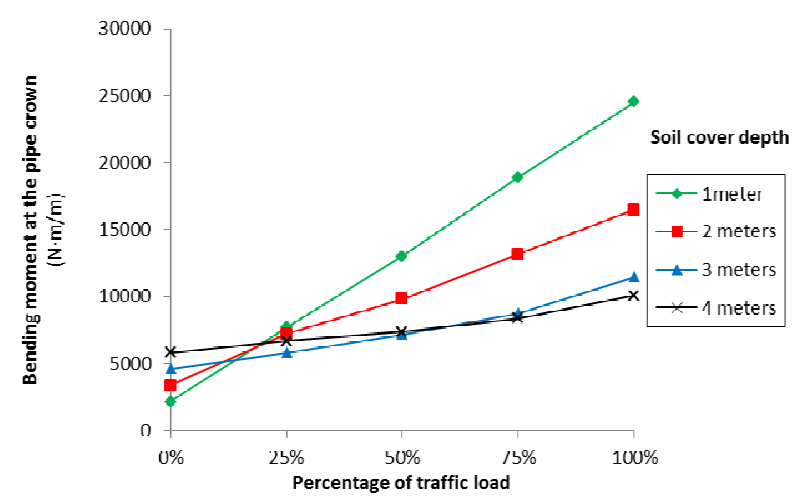

Fig. 16. Comparison of test results using heavy truck and differing soil cover depths

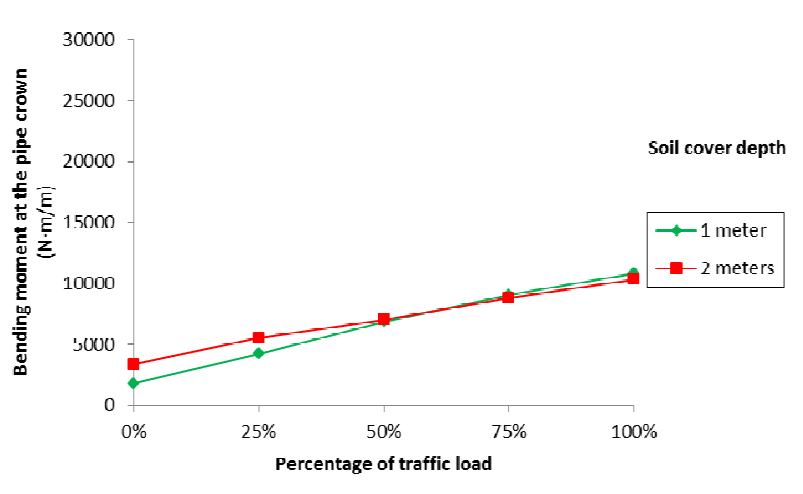

Fig. 17. Comparison of results using medium truck and differing soil cover depths

Comparison of bending moments at the pipe crown induced by the soil pressure

\begin{tabular}{|c|c|c|c|c|c|}
\hline $\mathrm{H}(\mathrm{m})$ & $\begin{array}{c}\mathrm{M}_{\mathrm{c}-\mathrm{s}} \\
(\mathrm{N} \cdot \mathrm{m} / \mathrm{m})\end{array}$ & $\begin{array}{c}\mathrm{M}_{1-\mathrm{s}} \\
(\mathrm{N} \cdot \mathrm{m} / \mathrm{m})\end{array}$ & $\mathrm{M}_{1-\mathrm{s}} / \mathrm{M}_{\mathrm{c}-\mathrm{s}}$ & $\begin{array}{c}\mathrm{M}_{2-\mathrm{s}} \\
(\mathrm{N} \cdot \mathrm{m} / \mathrm{m})\end{array}$ & $\mathrm{M}_{2-\mathrm{s}} / \mathrm{M}_{\mathrm{c}-\mathrm{s}}$ \\
\hline 1 & 2150 & 2328 & 1.08 & 4340 & 2.02 \\
\hline 2 & 3370 & 6544 & 1.94 & 8176 & 2.43 \\
\hline 3 & 4600 & 9459 & 2.06 & 11660 & 2.53 \\
\hline 4 & 5790 & 11329 & 1.96 & 15489 & 2.68 \\
\hline
\end{tabular}

Note:

H: soil cover depth.

$\mathrm{M}_{\mathrm{c}-\mathrm{s}}$ : Bending Moment induced by the soil pressure, measured in the centrifuge testing.

$\mathrm{M}_{1-s}$ : Bending Moment induced by the soil pressure, calculated using the traditional Marston-Spangler method.

$\mathrm{M}_{2-\mathrm{s}}$ : Bending Moment induced by the soil pressure, calculated using the ACPA method. 
It can be seen that the Boussinesq method gives a lower prediction than the test results. When the soil cover depth exceeds $3 \mathrm{~m}$, the calculated bending moment is only $1 / 3$ of the test result. The reason is that the Boussinesq method is based on theoretical analysis for a homogeneous, elastic and isotropic halfspace, while a large rigid concrete pipe buried in the soil would deviate from this assumption. The ACPA method gives a lower prediction than the test results at a soil cover depth of $1 \mathrm{~m}$ and $2 \mathrm{~m}$, while the prediction becomes slightly higher than the test results when the soil cover depth is $4 \mathrm{~m}$.

Finally, the total bending moments from dead and live loads were compared (Table 5). It can be seen that a combination of the Marston/Spangler method for dead load calculation and the Boussinesq method for live load calculation gives a lower bending moment for a shallow soil cover, e.g. $1 \mathrm{~m}$ and $2 \mathrm{~m}$, while the calculated bending moment becomes slightly higher than the experiment value for a deeper soil cover, e.g. $3 \mathrm{~m}$ and $4 \mathrm{~m}$. In contrast, the ACPA method only gives a lower (unconservative) value when the soil depth is $1 \mathrm{~m}$. The reason is that both the Boussinesq method and the ACPA method give lower bending moment values induced by heavy traffic load for a large diameter rigid pipe at a shallow soil cover (Table 4), while the bending moment induced by the shallow soil weight is not significant despite a conservative prediction (Table 3).

\section{Summary and conclusions}

A series of geotechnical centrifuge tests were carried out to study the performance of a large $1400 \mathrm{~mm}$-diameter reinforced concrete pipe with a footing subjected to heavy traffic loading. The influence of soil cover depth, as well as the positions and magnitude of traffic loads on the bending moments of a pipe were investigated. A heavy truck with a maximum load of $850 \mathrm{kN}$ was simulated in the majority of the tests, and a medium truck of $252 \mathrm{kN}$ was also simulated.

The centrifuge test results were found to be in reasonable agreement with those from full-scale tests. The pipe would experience the most unfavorable conditions when the heaviest (rear) axis of the traffic vehicle was located exactly above the pipe crown. At this position the bending moment at the pipe crown was two times more than that when the pipe was located between the front and rear axes.

A deeper soil cover would lead to higher initial stresses in the pipe, as well as a reduced influence of the traffic load. When the soil cover depth was increased from 1 to $4 \mathrm{~m}$, the initial bending moment induced by the soil weight was increased linearly by over two times, while the bending moment induced by the $100 \%$ heavy traffic load was decreased by over 5 times.

However, even at a soil cover depth of $4 \mathrm{~m}$, the bending moment induced by the heavy truck loading is significant compared with the bending moment induced by the soil cover weight and therefore it should not be ignored. In contrast, ACPA suggests the bending moment induced by AASHTO HS-20 load is insignificant at a soil cover depth exceeding $3.05 \mathrm{~m}(10 \mathrm{ft})$.

Comparisons were made between the centrifuge test results and several widely adopted design methods, highlighting the unconservative calculation results for large diameter rigid reinforced concrete

Comparison of bending moments at the pipe crown induced by the full traffic load

\begin{tabular}{|c|c|c|c|c|c|}
\hline $\mathrm{H}(\mathrm{m})$ & $\begin{array}{c}\mathrm{M}_{\mathrm{c}-\mathrm{t}} \\
(\mathrm{N} \cdot \mathrm{m} / \mathrm{m})\end{array}$ & $\begin{array}{c}\mathrm{M}_{1-\mathrm{t}} \\
(\mathrm{N} \cdot \mathrm{m} / \mathrm{m})\end{array}$ & $\mathrm{M}_{1-\mathrm{t}} / \mathrm{M}_{\mathrm{c}-\mathrm{t}}$ & $\begin{array}{c}\mathrm{M}_{2-\mathrm{t}} \\
(\mathrm{N} \cdot \mathrm{m} / \mathrm{m})\end{array}$ & $\mathrm{M}_{2-\mathrm{t}} / \mathrm{M}_{\mathrm{c}-\mathrm{t}}$ \\
\hline 1 & 22366 & 20460 & 0.91 & 14555 & 0.65 \\
\hline 2 & 13123 & 5115 & 0.39 & 10379 & 0.79 \\
\hline 3 & 6882 & 2273 & 0.33 & 6855 & 1.00 \\
\hline 4 & 4279 & 1273 & 0.30 & 5349 & 1.25 \\
\hline
\end{tabular}

Note:

H: soil cover depth.

$\mathrm{M}_{\mathrm{c}-\mathrm{t}}$ : Bending Moment induced by the full traffic load, measured in the centrifuge testing.

$\mathrm{M}_{1-\mathrm{t}}$ : Bending Moment induced by the full traffic load, calculated using the Boussinesq method.

$\mathrm{M}_{2-\mathrm{t}}$ : Bending Moment induced by the full traffic load, calculated using the ACPA method.

Comparison of total bending moments at the pipe crown

Table 5

\begin{tabular}{|c|c|c|c|c|c|}
\hline $\mathrm{H}(\mathrm{m})$ & $\begin{array}{c}\mathrm{M}_{\mathrm{c}-\mathrm{s}}+\mathrm{M}_{\mathrm{c}-\mathrm{t}} \\
(\mathrm{N} \cdot \mathrm{m} / \mathrm{m})\end{array}$ & $\begin{array}{c}\mathrm{M}_{1-\mathrm{s}}+\mathrm{M}_{1-\mathrm{t}} \\
(\mathrm{N} \cdot \mathrm{m} / \mathrm{m})\end{array}$ & $\left(\mathrm{M}_{1-\mathrm{s}}+\mathrm{M}_{1-\mathrm{t}}\right) /\left(\mathrm{M}_{\mathrm{c}-\mathrm{s}}+\mathrm{M}_{\mathrm{c}-\mathrm{t}}\right)$ & $\begin{array}{c}\mathrm{M}_{2-\mathrm{s}}+\mathrm{M}_{2-\mathrm{t}} \\
(\mathrm{N} \cdot \mathrm{m} / \mathrm{m})\end{array}$ & $\left(\mathrm{M}_{2-\mathrm{s}}+\mathrm{M}_{1-\mathrm{t}}\right) /\left(\mathrm{M}_{\mathrm{c}-\mathrm{s}}+\mathrm{M}_{\mathrm{c}-\mathrm{t}}\right)$ \\
\hline 1 & 24516 & 22788 & 0.93 & 20220 & 0.82 \\
\hline 2 & 16493 & 11659 & 0.71 & 19880 & 1.21 \\
\hline 3 & 11482 & 11733 & 1.02 & 19840 & 1.73 \\
\hline 4 & 10069 & 12602 & 1.25 & 22160 & 2.20 \\
\hline
\end{tabular}




\section{Теория расчета строительных конструкций}

pipes lying at a shallow soil cover depth, when heavy traffic load is applied at the ground surface.

It should be noted that the pipe was subjected to static loading during the geotechnical centrifuge tests presented in this paper. Further research would be necessary to examine the influence of cyclic loading from heavy vehicles on large reinforced concrete pipes.

\section{Acknowledgments}

The authors are grateful for the research support received from National Natural Science Foundation of China (51350110231 and 41272280), and 973 Program (2010CB732103). The assistance of Ruihua Zheng and Lifeng Shi with conducting the centrifuge testing is also gratefully acknowledged.

\section{References}

1. Cohen B. Fixing America's Crumbling Underground Water Infrastructure: Competitive Bidding Offers A Way Out. Competitive Enterprise Institute. Washington, DC. 2012.

2. Ministry of Housing and Urban-Rural Development, P.R. China. China Urban Construction Statistical Yearbook 2009, China Planning Press. 2010.

3. Recio J.M.B., Guerrero P.J., Ageitos M.G., Narvaez R.P.; Estimate of energy consumption and $\mathrm{CO} 2$ emissions associated with the production, use and final disposal of PVC, HDPE, PP ductile iron and concrete pipes. Barcelona, 2005.

4. Clayton C.R.I., Xu M., Whiter J.T., Ham A. and Rust M. Stresses in cast - iron pipes due to seasonal shrink - swell of clay soils. Water Management, 2010, 163 (WM3): 157-162.

5. Davies J.P., Clarke B.A., Whiter J.T., Cunningham R.J. Factors influencing the structural deterioration and collapse of rigid sewer pipes. Urban Water, 2001, 3 (1-2): 73-89.

6. Lester J., and Farrar D.M. 1979. An examination of the defects observed in $6 \mathrm{~km}$ of sewers. TRRL Supplementary Report 531.

7. Trott J.J., and Gaunt J. Results of some recent field experiments on underground pipelines. In Proceedings of the Symposium: Research and Development sewerage and drainage design. India, 14 May 1975, Institution of public health Engineers, 1975.

8. U.S. Federal Highway Administration. 2000. Comprehensive Truck Size and Weight Study. Publication Number: FHWA-PL-00-029.

9. Boussinesq J. Application des potentials a l'etude de l'equilibre et du mouvement des solides elastiques, Gauthier-Villars, Paris, 1883.

10. Young O.C., and O'Reilly M.P. A guide to design loadings for buried rigid pipes. TRRL, Department of Transport, 1993.

11. British Standards Institution. 1998. BS EN 1295-1: Structural design of buried pipelines under various conditions of loading: Part 1 General requirements, BSI, London.

12. Marston A., and Anderson A.O. The theory of loads on pipes in ditches and tests of cement and clay drain tile and sewer pipes. Bulletin 31. Ames (Iowa): Iowa Engineering Experiment Station, 1913.

13. Spangler M.G. The supporting strength of rigid pipe culverts. Bulletin 112. (IA): Iowa State College, 1933.

14. Burns J.Q., and Richard R.M. Attenuation of stresses for buried cylinders. In Proceedings of the symposium on soil-structure interaction. Tucson (AZ): University of Arizona Engineering Research Laboratory, 8-11 June 1964. American Society for Testing and Materials, West Conshohocken, PA, 1964, pp. 379-392.

15. The Freedonia Group. Large Diameter Pipe to 2016 - Industry Market Research, Market Share, Market Size, Sales, Demand Forecast, Market Leaders, Company Profiles, Industry Trends. Industry Study 2974. 2012.

16. Pocock R.G., Lawrence G.J.L., and Taylor M.F. Behaviour of a shallow buried pipeline under static and rolling wheel loads. TRRL Laboratory Report 954. 1980.

17. Taylor M.E., and Lawrence G.J.L. Measuring the effects of traffic induced stresses on small diameter pipeline. Pipe and pipeline international, 1985, 30 (2): 15-19.

18. Arockiasamy M., Chaallal O., and Limpeteeprakarn T. Full-scale field tests on flexible pipes under live load application. Journal of Performance of Constructed Facilities, 2006, 20 (1): 21-27.

19. Moore I.D., Becerril Garcia D., Sezen H. and Sheldon T. Structural design requirements for culvert joints, NCHRP Web-only document 190, Contractor's Final Report for NCHRP Project 15-38, April 2012 Transportation Research Board, Washington D.C., 2012.

20. Allan H.A. Structural design of buried rigid pipelines a comparative study of international practice. In Proceedings of the International conference on the planning, construction, maintenance and operation of sewerage systems, Reading, UK, September 1984.

21. Saiyar M. Behaviour of buried pipelines subject to normal faulting. Ph.D. thesis, Department of Civil Engineering, Queen's University, Kingston, Ontario, Canada, 2011.

22. White D.J., Barefoot A.J. and Bolton M.D. Centrifuge modeling of upheaval buckling in sand. International Journal of Physical Modelling in Geotechnics, 2001, 1 (2): 19-28.

23. Cheuk C.Y., Take W.A., Bolton M.D. and Oliveira, J.R.M.S. Soil restraint on buckling oil and gas pipelines buried in lumpy clay fill. Engineering Structures, 2007, 29 (6): 973-982. 
24. Trott J.J., Taylor R.N., and Symons I.F. Tests to validate centrifuge modeling of flexible pipes. In Proceedings of a symposium on the application of centrifuge modeling to geotechnical design, Manchester, 16-18 April 1984. A.A. Balkema, Rotterdam, Boston, 1985, pp. 223-251.

25. Marshall A.M., Klar A., and Mair R.J. Tunneling beneath buried pipes: view of soil strain and its effect on pipeline behavior. Journal of Geotechnical and Geoenvironmental Engineering, 2010, 136 (12): 1664-1672.

26. Schofield A.N. Cambridge geotechnical centrifuge operations. Géotechnique, 1980, 30 (3): $227-268$.

27. Hu Y., Zhang G., Zhang J.M. and Lee C.F. Centrifuge modeling of geotextile-reinforced cohesive slopes. Geotextiles and Geomembranes, 2010, 28 (1): 12-22.

28. British Standards Institution. 2002. BS EN 1916: Concrete pipes and fittings, unreinforced, steel fibre and reinforced, BSI, London.

29. Rajani B., and Abdel-Akher A. Performance of Cast-Iron-Pipe Bell-Spigot Joints Subjected to Overburden Pressure and GroundMovement. Journal of Pipeline Systems Engineering and Practice, 2013, 4 (2): 98-114.
30. SNIP. 2006. 2.02.01-83*, Foundations of buildings and structures. The Center of Construction Design Documentation, Moscow.

31. Rakitin B.A. Stress-strain state of large diameter non-pressure reinforced concrete pipes. $\mathrm{Ph} . \mathrm{D}$. thesis, Department of Civil Engineering, South Ural State University, Chelyabinsk, Russia, 2010.

32. American Concrete Pipe Association (ACPA). 2011. Concrete Pipe Design Manual [ebook]. Available at: http://www.concrete-pipe.org/ pages/design-manual.html. [accessed 7 May 2013].

33. Di Prisco C., and Galli A. Soil-pipe interaction under monotonic and cyclic loads: experimental and numerical modeling. In Proceedings of the First Euromediterranean Symposium on Advances in Geomaterials and Structures, Hammamet, Tunisia, 35 May, 2006. Commission universitaire pour le developpment, Tunis, 2006, pp. 755-760.

34. McAffee R.P., and Valsangkar A.J. Field performance, centrifuge testing, and numerical modelling of an induced trench installation. Canadian Geotechnical Journal, 2008, 45 (1): 85-101.

35. Watkins R.K., and Anderson L.R. Structural mechanics of buried pipes. CRC Press LLC, Boca Raton London New York Washington, D.C. 2000.

Received 26 April 2016

\title{
ИСПЫТАНИЯ В ЦЕНТРИФУГЕ ТРУБ БОЛЬШОГО ДИАМЕТРА ПОД ВОЗДЕЙСТВИЕМ ТЯЖЕЛЫХ ГРУЗОВ
}

\author{
Б. Ракитин, Мине Су \\ Университет Циньхуа, Пекин, Китай
}

Трубы большого диаметра, так же как автомобили большой грузоподъемности, получают все более широкое распространение, что вызывает неопределенность в отношении проектирования трубы. В данной статье описаны процедура и результаты серии геотехнических испытаний в центрифуге, которые проводились на железобетонной трубе диаметром 140 мм на фундаменте под воздействием тяжелого транспорта. Изучены влияние глубины грунта, положение и нагрузка транспортного средства на изгибающий момент трубы. В большинстве тестов был смоделирован тяжелый грузовик с максимальной погрузкой 850 кНм, а также грузовик средней грузоподъемности в 252 кНм. Результаты испытаний в центрифуге соответствуют результатам испытаний в натуральном масштабе. Наиболее сильное влияние на трубу обнаружено в положении, когда самая тяжелая ось грузовика находилась точно над сечением трубы. В более глубоких слоях грунта первоначальное давление в трубе сильнее, в то время, как меньше нагрузка от транспортного средства. Однако даже при глубине грунта в 4 мм изгибающий момент трубы значительный под воздействием тяжелого транспортного средства, что необходимо учитывать при проектировании трубы. Проведен сравнительный анализ 
результатов испытаний в центрифуге и некоторых широко используемых методов проектирования, получены неожиданные результаты расчетов для жестких труб большого диаметра на небольшой глубине грунта под воздействием транспортного средства большой грузоподъемности.

Ключевые слова: взаимодействие сооружения с грунтом, железобетонная труба, грузы тяжелого транспортного средства, геотехническое испытание в центрифуге, испытания в натуральном масштабе.

Ракитин Борис, постдокторант кафедры «Гражданское строительство», университет Циньхуа, Пекин, Китай, boris.rakitin@gmail.com

Минг Су, доцент кафедры «Гражданское строительство», университет Циньхуа, Пекин, Китай.

Поступила в редакцию 26 апреля 2016 2.

\section{ОБРАЗЕЦ ЦИТИРОВАНИЯ}

Rakitin, B. Centrifuge modeling of large diameter underground pipes subjected to heavy traffic loads / B. Rakitin, Ming Хu // Вестник ЮУрГУ. Серия «Строительство и архитектура». - 2016. - Т. 16, № 3. - С. 31-46. DOI: $10.14529 /$ build 160305

\section{FOR CITATION}

Rakitin B., Ming Xu. Centrifuge Modeling of Large Diameter Underground Pipes Subjected to Heavy Traffic Loads. Bulletin of the South Ural State University. Ser. Construction Engineering and Architecture. 2016, vol. 16, no. 3, pp. 31-46. DOI: 10.14529/build160305 